\title{
Negative correlation between cross-linked fibrin degradation products (D-dimer) and Glasgow Coma Scale (GCS) in patients with traumatic brain injury
}

\author{
Andriani Tri Susilowati ${ }^{*}$, Usi Sukorini ${ }^{2}$, Setyawati ${ }^{2}$ \\ ${ }^{1}$ Ambarawa District Hospital, Central Java, ${ }^{2}$ Departement of Clinical Pathology, Faculty \\ of Medicine, Universitas Gadjah Mada, Yogyakarta, Indonesia
}

\section{ABSTRACT}

Traumatic brain injury (TBI) is damage in the brain caused by a traumatically injuring external force. The severity of TBI can be determined by Glasgow Coma Scale (GCS) and Computed Tomography (CT) scan. However, due to the heightened concerns about use of CT scan, an objective laboratory-based predictor of significant TBI is needed. The level of plasma crosslinked fibrin degradation products (D-dimer) after TBI has been promoted as prognostic factor for an intracranial hemorrhage injury. The aim of this study was to evaluate the correlation between plasma D-dimer level and GCS score in patients with TBI. This was an observational analytic study with cross sectional design. Subjects were TBI patients who came to the Department of Emergency, Dr. Sardjito General Hospital, Yogyakarta and met the inclusion and exclusion criteria. The severity of TBI of patients was measured using the GCS which included the assessment of eye opening, motoric response, and verbal response. Supporting examinations including radiological (CT scan) and laboratory examination were also conducted. The plasma D-dimer level was measured using an immunofiltration method from NycoCard ${ }^{\oplus} \mathrm{D}$-Dimer. The results showed that a significant negative correlations between D-dimer level $(r=-0.622 ; p=0.000)$, neutrophil $(r=-0.336 ; p=0.034)$ and partial thromboplastin time (PTT) $(r=-0.591 ; r=0.000)$ of subjects and GCS score were observed. Conversely, a significant positive correlation was shown between haemoglobin $(r=0.419 ; p=0.007)$ and GCS score. Furthermore, a significant negative correlations were observed between haemoglobin $(r=-0.517 ; p=0.001)$, platelets $(r$ $=-0.340 ; \mathrm{p}=0.032$ ) and D-dimer level. Otherwise, a significant positive correlation was observed between PPT levels $(r=0.527 ; p=0.000$ ) of subjects and D-dimer level. In conclusion, there is a negative correlation between plasma D-dimer level and GCS in patients with TBI.

\section{ABSTRAK}

Cedera kepala merupakan kerusakan kepala yang disebabkan oleh benturan fisik dari luar. Keparahan cidera kepala dapat diukur dengan Glasgow Coma Scale (GCS) dan Computed Tomography (CT) scan. Namun demikian, kekhawatiran akan penggunaan CT scan suatu prediktor berdasarkan pemeriksaan laboratorium yang objektif diperlukan untuk mengukur cedera kepala. Kadar plasma cross-linked fibrin degradation products (D-dimer) setelah cedera kepala diusulkan sebagai faktor prognosis untuk cidera pendarahan intrakranial. Tujuan penelitian ini adalah mengkaji hubungan antara kadar D-dimer plasma dengan nilai GCS pasien cedera kepala. Penelitian ini merupakan penelitian analitik observasional dengan rancangan potong silang. Subjek adalah penderita cedera kepala yang datang ke Instalasi Rawat Darurat (IRD), RSUP Dr. Sardjito, Yogyakarta yang memenuhi kriteria inklusi dan eksklusi. Tingkat keparahan cedera otak penderita diukur dengan GCS yang meliputi respon mata, respon motorik dan respon verbal. Pemeriksaan pendukung yang meliputi CT scan dan pemeriksaan laboratorium juga dilakukan. Kadar D-dimer plasma diukur dengan metode imunofiltrasi dari $\mathrm{NycoCard}^{\circledR} \mathrm{D}$-Dimer. Hasil penelitian menunjukkan

\footnotetext{
* corresponding author: andrianitrisusilowati@yahoo.com
} 


\begin{abstract}
adanya hubungan negatif secara nyata antara kadar D-dimer $(r=-0,622 ; p=0,000)$, neutrofil $(r=-0,336 ; p=0,034)$ dan PPT $(r=-0,591 ; r=0,000)$ penderita dan skor GCS. Sebaliknya, terdapat hubungan negatif secara nyata antara hemoglobin $(r=0,419 ; p=0,007)$ dan skor GCS. Selanjutnya, terdapat hubungan negatif secara nyata antara hemoglobin $(r=-0,517 ; p=$ $0,001)$, platelet $(r=-0,340 ; p=0,032)$ dengan kadar D-dimer. Sebaliknya, hubungan positif secara nyata ditunjukkan antara kadar PPT $(r=0,527 ; p=0,000)$ penderita dengan kadar Ddimer. Dapat disimpulkan, terdapat hubungan negatif antara kadar D-dimer plasma dengan skor GCS pada penderita cedera kepala.
\end{abstract}

Key words: D-dimer - glasgow coma scale - traumatic brain injury - CT scan - correlation

\section{INTRODUCTION}

The incidence of traumatic brain injury (TBI) increases rapidly in almost every country in the world, reaching 200 cases per 100,000 populations annually. In the United States, appoxinately 1.4 million people with a TBI has been reported annually and about one million of the victims need hospitalization for both inpatient or outpatient treatment. Among 235,000 the victims treated, 50,000 of them died. Moreover, between 80,000 and 90,000 victims suffer permanent disability due to head injury. It is estimated that the prevalence of the TBI in the United State reaches 5.3 million people or $2 \%$ of the population. ${ }^{1,2}$

The severity of TBI can be determined by Glassgow Coma Scale (GCS) and Computed Tomography (CT) scan. ${ }^{3,4}$ According to the GCS, head injuries are classified as mild TBI (GCS of 13 to 15), moderate TBI (GCS of 9 to 12) or severe TBI (GCS of 4 to 8 ) and require at least one time of a CT-scan and an X-ray examination. ${ }^{3}$ The $\mathrm{CT}$ scan is conducted if an intracranial hemorrhage is suspected. Computed Tomography scan has advantages to detect the location and the area of suspected intracranial hemorrhage. It is a painless non invasive procedure with good sensitivity to detect pathology of the head. ${ }^{5}$ However, CT scan may also has disadvantages such as associated with recource utilization and the clinical consequences of radiation. Therefore, it should not be used repeatedly in children because of the repeated radiation exposure. ${ }^{6}$

Due to the heightened concerns about use of CT scan and the limitations of clinical scoring systems of the GCS, an objective laboratorybased predictor of significant TBI is needed. The level of plasma cross-linked fibrin degradation products (D-dimer) after TBI can be a useful prognostic factor for an intracranial hemorrhage injury. ${ }^{7,8}$ The plasma D-dimer level as predictor of TBI has been investigated by some authors. Swanson et al. ${ }^{9}$ reported that a low plasma D-dimer was associated with the absence of significant brain injury. Furthermore, Kuo et al. ${ }^{10}$ showed that a high plasma D-dimer level was associated with a poor outcome in patients with traumatic intracranial hemorrhage. This study aimed to investigate the correlation between the plasma D-dimer level and GCS score in patients with TBI who came to the Department of Emergency, Dr. Sardjito General Hospital, Yogyakarta.

\section{MATERIALS AND METHODS}

\section{Subjects}

The study protocol was approved by the Medical and Health Research Ethics Committee, Faculty of Medicine, Universitas Gadjah Mada, Yogyakarta. This was an observational study with cross-sectional design performed in Department of Emergency and Department of Clinical Pathology, Dr. Sardjito General 
Hospital/Faculty of Medicine, Universitas Gadjah Mada, Yogyakarta over a three-month period from November 2012 to January 2013 or after the minimal sample size were obtained consecutively as many as 40 subjects. Subjects were TBI patients who came in Department of Emergency and were selected to met the inclusion and exclusion criteria.

The inclusion criteria were (a) the new head-injured patients who came to Department of Emergency, (b) aged 15-65 years old, (c) onset less than 24 hours, (d) single and had multiple types of trauma, and (e) the number of GCS score of 4-15. The exclusion criteria were (a) having a history of pulmonary embolism and deep venous thrombosis (DVT) measured with Wells score (if Wells score was less than 2, subjects were considered no risk of pulmonary embolism or DVT), (b) having a history of malignancy, liver diseases, stroke and diabetes mellitus, (c) pregnant women, (c) underwent major surgery for less than 3 months, (d) having a history of alcohol use, (d) using antiplatelet aggregation, aspirin or anticoagulan coumarin (e.g. warfarin) and heparin, (e) speech and hearing impaired, (f) having a history of the brain (e.g. cerebral palsy) and motor disorders. The subjects who did not meet the inclusion and exclusion criteria using autoanamnesis and alloanamnesis were excluded from the study.

\section{Protocol of study}

Patients who came in the Department of Emergency with suspected TBI were considered to be involved in this study. After informed consents were obtained from the patients, the TBI examination was performed by autoanamnesis and alloanamnesis. For patients who met the inclusion and exclusion criteria, physical examinations of TBI including blood pressure, temperature, repiratory rate and level of awareness were then conducted. The level of awareness of patients was measured using the GCS which included the assessment of (E) ye opening, (M) otorik response, (V) erbal response. The GCS was then used to categorise head injuries into three categories as mild TBI (GCS 13-15), moderate TBI (GCS 9-12) and severe TBI (GCS 3-8). Supporting examination to identify TBI namely radiological and laboratory examination were also conducted. The radiological examination using CT scan was conducted to identify fractures, intracranial hemorrhage, extensive and location of bleeding lesions. The laboratory examination included a complete blood count, blood electrolytes, pothrombin time (PT), plasma prothrombin time (PPT), activated partial thromboplastin time (APTT) and plasma D-dimer levels.

\section{Plasma D-dimer measurement}

The plasma D-dimer levels were measured using an immunofiltration method from NycoCard ${ }^{\circledR}$ D-Dimer in Department of Clinical Pathology. Three mL blood samples of patients were drawn in evacuated blood collecting tubes for coagulation analyses ( $0.13 \mathrm{M}$ na-citrate) when they first came to the Department of Emergency. The blood samples were then centrifuged for 15 minutes at $2000 \mathrm{~g}$. The plasma samples were collected and kept frozen at " $20^{\circ} \mathrm{C}$ until analyzed. The plasma samples were thawed in a waterbath at $37{ }^{\circ} \mathrm{C}$ for 15 minutes before analyzed. Fifty $\mu \mathrm{L}$ of washing solution was applied to test well containing a membrane coated with a human anti D-dimer monoclonal antibodies. Fifty $\mu \mathrm{L}$ of the plasma sample was then added and the well was then washed. Fifty $\mu \mathrm{L}$ of conjugate solution containing a second human anti D-dimer monoclonal antibodies labelled with ultra-small gold particles was added and the well was then washed again. The intensity of colour change, generated by the presence of any bound gold particles, was proportional to the plasma D-dimer level (ng/ $\mathrm{mL}$ ) present in the sample. The colour change 
of the test well was measured using a reflectance meter (Nyco-Card Reader II, Nycomed Pharma AS). Validation of the plasma D-dimer measurement was determined before analysis.

\section{Statistical analysis}

Data were presented as mean \pm standard deviation (SD). The relationship between levels of D-dimer with a GCS score was analyzed using Pearson correlation test. Ap value $<0.05$ was considered as significant.

\section{RESULTS}

Validation of plasma D-dimer analysis method provided a coefficient of variation value within day of $3.4 \%$ at mean levels of $1,280 \mathrm{ng} /$ $\mathrm{mL}$. The coeffeicient of variation value accepted by the manufacturer's claim was $\square 15 \%$ at mean levels of $\square 10,000 \mathrm{ng} / \mathrm{mL} .^{11}$ The accuracy obtained from the analysis method was $97.8 \%$ at mean levels of $1,350 \mathrm{ng} / \mathrm{mL}$. The accuracy recommended was $>90 \%{ }^{12}$

The mean plasma D-dimer levels based on the characteristics of subject is presented in TABLE 1 . The head injury was more observed on a young age of $15-45$ years $(82.5 \%)$ than the age of $45-65$ years $(17.5 \%)$. The cause of most head injuries was traffic accidents $(80 \%)$ followed by falling from high places at work $(15 \%)$ and by beating $(5 \%)$. The male subjects $(70 \%)$ had more TBI than female subjects (30\%). Most of the head injuries were mild ijuries $(70 \%)$ followed by moderate injuries $(25 \%)$ and severe injuries $(5 \%)$. In addition, most subjects had single TBI $(65 \%)$ with the most of onset of $\square 12$ hours (85\%).

TABLE 1. Plasma D-dimer levels based on characteristics of subject

\begin{tabular}{|c|c|c|c|}
\hline Variables & n $(\%)$ & $\begin{array}{l}\text { Plasma D-dimer levels } \\
(\text { Mean } \pm \mathrm{SD} \text { in } \mathrm{ng} / \mathrm{mL} \text { ) }\end{array}$ & $\mathrm{p}$ \\
\hline \multicolumn{4}{|l|}{$\mathrm{Age}^{\mathrm{a}}$} \\
\hline$-\quad 15-45$ & $33(82.5)$ & $1736.36 \pm 1953.01$ & \multirow{2}{*}{0.534} \\
\hline$-46-65$ & $7(17.5)$ & $2271.43 \pm 2496.47$ & \\
\hline \multicolumn{4}{|l|}{$\operatorname{Sex}^{\mathrm{a}}$} \\
\hline - Male & $28(70)$ & $1478.57 \pm 1672.51$ & \multirow{2}{*}{0.095} \\
\hline - Female & $12(30)$ & $2650.00 \pm 2594.58$ & \\
\hline \multicolumn{4}{|l|}{ Cause } \\
\hline - Vehicle (active) & $26(65)$ & $1276.92 \pm 1330.36$ & \multirow{4}{*}{0.102} \\
\hline - Falling & $6(15)$ & $2400.00 \pm 225.33$ & \\
\hline - Beating & $2(5)$ & $3500.00 \pm 4625.48$ & \\
\hline $\begin{array}{ll}\text { - } & \text { Vehicle } \\
& \text { (passive) }\end{array}$ & $6(15)$ & $3100.00 \pm 3029.85$ & \\
\hline \multicolumn{4}{|l|}{ Classification ${ }^{b}$} \\
\hline - Severe & $2(5)$ & $6250,00 \pm 3181.98$ & \multirow{3}{*}{$0.000 * *$} \\
\hline - Moderate & $10(25)$ & $2720.00 \pm 2007.65$ & \\
\hline - Mild & $28(70)$ & $1196.43 \pm 1446.19$ & \\
\hline \multicolumn{4}{|l|}{ Types of injury ${ }^{a}$} \\
\hline - Single & $26(65)$ & $1653.85 \pm 1764.14$ & \multirow{2}{*}{0.462} \\
\hline - Multiple & $14(35)$ & $2157.14 \pm 2496.06$ & \\
\hline
\end{tabular}


Susilowati et al., Negative correlation between cross-linked fibrin degradation products (D-dimer) and Glasgow Coma Scale (GCS) in patients with traumatic brain injury

TABLE 1. Plasma D-dimer levels based on characteristics of subject (continued)

\begin{tabular}{|c|c|c|c|}
\hline Variables & $\mathrm{n}(\%)$ & $\begin{array}{l}\text { Plasma D-dimer levels } \\
\text { (Mean } \pm \text { SD in ng/mL) }\end{array}$ & $\mathrm{p}$ \\
\hline \multicolumn{4}{|l|}{ Onset $^{\mathrm{a}}$} \\
\hline$-<12$ hour & $34(85)$ & $1911.76 \pm 2044.60$ & \multirow{2}{*}{0.552} \\
\hline$-\quad \geq 12$ hour & $6(15)$ & $1366.67 \pm 2080.06$ & \\
\hline \multicolumn{4}{|l|}{ Sodium $^{c}$} \\
\hline$-<135 \mathrm{mmol} / \mathrm{L}$ & $5(12.5)$ & $2060.00 \pm 3600.42$ & \multirow{2}{*}{0.608} \\
\hline$-\quad \geq 135 \mathrm{mmol} / \mathrm{L}$ & $35(87.5)$ & $1847.06 \pm 1792.11$ & \\
\hline \multicolumn{4}{|l|}{ Pottasium $^{\mathrm{a}}$} \\
\hline$-<3.5 \mathrm{mmol} / \mathrm{L}$ & $12(30)$ & $1900.00 \pm 2025.74$ & \multirow{2}{*}{0.959} \\
\hline$-\quad \geq 35 \mathrm{mmol} / \mathrm{L}$ & $28(70)$ & $1862.96 \pm 2083.66$ & \\
\hline \multicolumn{4}{|l|}{ Leucocyte $^{c}$} \\
\hline$-<11(\mathrm{x} 10 / \mu \mathrm{L})^{3}$ & $8(20)$ & $1487.50 \pm 2904.89$ & \multirow{2}{*}{0.06} \\
\hline$-\geq 11(\mathrm{x} 10 / \mu \mathrm{L})^{3}$ & $32(80)$ & $1915.62 \pm 1803.78$ & \\
\hline \multicolumn{4}{|l|}{ Neutrophil $^{\mathrm{a}}$} \\
\hline$-\quad=65 \%$ & $5(12)$ & $1360.00 \pm 1171.75$ & \multirow{2}{*}{0.587} \\
\hline$->65 \%$ & $35(87)$ & $1897.14 \pm 2130.66$ & \\
\hline \multicolumn{4}{|l|}{ Haemoglobin $^{\mathrm{a}}$} \\
\hline$-<10 \mathrm{~g} / \mathrm{dL}$ & $4(10)$ & $3875.00 \pm 3816.08$ & \multirow{2}{*}{$0.002 *$} \\
\hline$-\quad \geq 10 \mathrm{~g} / \mathrm{dL}$ & $36(90)$ & $1602.78 \pm 1680.39$ & \\
\hline \multicolumn{4}{|l|}{ Platelets $^{\mathrm{a}}$} \\
\hline$-<150.000$ & $8(20)$ & $236.86 \pm 72.446$ & \multirow[t]{2}{*}{0.948} \\
\hline$-\geq 150.000$ & $32(80)$ & $233.88 \pm 11.5 .401$ & \\
\hline \multicolumn{4}{|l|}{$\mathrm{PT}^{\mathrm{a}}$} \\
\hline$-\leq 16.3$ second & $36(90)$ & $1652.78 \pm 1784.13$ & \multirow{2}{*}{0.077} \\
\hline - $>16.3$ second & $4(10)$ & $3425.00 \pm 3577.12$ & \\
\hline \multicolumn{4}{|l|}{ APTT $^{\mathrm{a}}$} \\
\hline$-\leq 37$ second & $38(95)$ & $1692.11 \pm 1754.13$ & \multirow{2}{*}{0.06} \\
\hline - $>37$ second & $2(5)$ & $4450.00 \pm 5727.56$ & \\
\hline \multicolumn{4}{|l|}{ Blccding (CT scan $)^{a}$} \\
\hline - No & $32(80)$ & $1356.25 \pm 1560.17$ & \multirow{2}{*}{$0.002 *$} \\
\hline - Yes & $8(20)$ & $3725.00 \pm 2665.52$ & \\
\hline
\end{tabular}

${ }^{a}$ Independent $t$-test; ${ }^{b}$ One way Anova; ${ }^{c}$ Mann-Whitney test; *Significant $(p<0.05)$;

** Significant $(p<0.05)$

The correlation between the laboratory varibales of subjects and their GCS score are presented in TABLE 2. A significant positive correlation between haemoglobin $(r=0.419 ; p$ $=0.007)$ and a significant negative correlation between neutrophil $(\mathrm{r}=-0.336 ; \mathrm{p}=0.034)$ and PPT levels $(\mathrm{r}=-0.591 ; \mathrm{p}=0.000)$ of subjects with their GCS score were observed in this study. Otherwise, no correlation was observed between the onset of head injury, blood pressure, blood electrolite, blood glucose, platelets and APTT levels of subjects with GCS score $(\mathrm{p}>0.05)$. 
TABLE 2. Correlations between the laboratory varibales of subjects with GCS score

\begin{tabular}{lcc}
\hline & \multicolumn{2}{c}{$\mathrm{GCS}$} \\
\cline { 2 - 3 } Variables & $\begin{array}{c}\text { Correlation } \\
(\mathrm{r})\end{array}$ & $\mathrm{p}$ \\
\hline Onset (hour) & -0.126 & 0.439 \\
Systolic BP $(\mathrm{mmHg})$ & -0.195 & 0.229 \\
Sodium $(\mathrm{mmol} / \mathrm{dL})$ & -0.139 & 0.394 \\
Potassium $(\mathrm{mmol} / \mathrm{dL})$ & 0.025 & 0.877 \\
Glucose $(\mathrm{g} / \mathrm{dL})$ & -0.219 & 0.206 \\
Hacmoglobin $(\mathrm{g} / \mathrm{dL})$ & 0.419 & $0.007^{*}$ \\
Leukocyte $\left(\mathrm{x} 10^{3} / \mu \mathrm{L}\right)$ & -0.261 & 0.104 \\
Neutrophil $(\%)$ & -0.336 & $0.034^{* *}$ \\
Platelets $\left(\mathrm{x} 10^{3} / \mu \mathrm{L}\right)$ & 0.290 & 0.070 \\
PPT $(\mathrm{second})$ & -0.591 & $0.000^{*}$ \\
APPT $(\mathrm{second})$ & -0.278 & 0.083 \\
\hline PPT $=$ plasma prothrombin time; APPT $=$ activated \\
plasma prothrombin time; ${ }^{*}$ Pearson correlation test; \\
${ }^{* *}$ Spearman test & \multicolumn{2}{|}{}
\end{tabular}

TABLE 3 presents the correlation between the clinical (GCS) and laboratory variables of subjects and their plasma D-dimer level. A strong significant negative correlation between the clinical (GCS) score of subjects with the plasma D-dimer level was observed in this study $(r=0.622 ; p=0.000)$. A significant negative correlation between haemoglobin $(\mathrm{r}=$ $-0.517 ; \mathrm{p}=0.001)$, platelets $(\mathrm{r}=-0.340 ; \mathrm{p}=$ 0.032 ) and a significant positive correlation between PPT levels $(r=0.527 ; p=0.000)$ of subjects with their plasma D-dimer level were also observed in this study. However, no correlation was observed between the age, onset of head injury, blood pressure, blood electrolite, blood glucose, leucocyte, neutophil and APTT levels of subjects with the plasma D-dimer level ( $\mathrm{p}>0.05)$.
TABLE 3. Correlations between the clinical (GCS) and laboratory varibales of subjects with the plasma D-dimer level

\begin{tabular}{lcc}
\hline \multirow{2}{*}{ Variab les } & \multicolumn{2}{c}{ D-Dimer } \\
\cline { 2 - 3 } & $\begin{array}{c}\text { Correlation } \\
(\mathrm{r})\end{array}$ & $\mathrm{p}$ \\
\hline GCS & -0.622 & $0.000^{*}$ \\
Age (years) & 0.06 & 0.712 \\
Onset (hour) & 0.027 & 0.867 \\
Systolic BP (mmHg) & 0.12 & 0.461 \\
Sodium $(\mathrm{mmol} / \mathrm{dL})$ & -0.129 & 0.426 \\
Potassium $(\mathrm{mmol} / \mathrm{dL})$ & 0 & 0.998 \\
Glucose $(\mathrm{g} / \mathrm{dL})$ & 0.231 & 0.181 \\
Haemoglobin $(\mathrm{g} / \mathrm{dL})$ & -0.517 & $0.001^{*}$ \\
Leucocyte $\left(\mathrm{x} 10^{3} / \mu \mathrm{L}\right)$ & 0.292 & 0.067 \\
Neutrophil $(\%)$ & 0.226 & 0.095 \\
Platelets $\left(\mathrm{x} 10^{3} / \mu \mathrm{L}\right)$ & -0.34 & $0.032^{*}$ \\
PPT (second) & 0.527 & $0.000^{*}$ \\
APPT (second) & 0.271 & 0.091 \\
\hline
\end{tabular}

*Pearson correlation test; ${ }^{* *}$ Spearman test

No significant correlatioan between all laboratory variables with plasma D-dimer level in patients with a GCS score $\square 12$ was observed in this study (TABLE 4).

TABLE 4. Correlation between laboratory variables with plasma D-dimer level in patients with a GCS score d" $12(\mathrm{n}=12)$

\begin{tabular}{lcc}
\hline \multirow{2}{*}{ Variables } & \multicolumn{2}{c}{ D-dimer } \\
\cline { 2 - 3 } & $\begin{array}{c}\text { Correlation } \\
(\mathrm{r})\end{array}$ & $\mathrm{p}^{*}$ \\
\hline Haemoglobin $(\mathrm{gr} / \mathrm{dL})$ & -0.516 & 0.086 \\
Leucocyte $\left(\mathrm{x} 1 \mathrm{\sigma}^{3} / \mu \mathrm{L}\right)$ & -0.203 & 0.527 \\
Neutrophil $(\%)$ & 0.322 & 0.308 \\
Platelets $\left(\mathrm{x} 10^{3} / \mu \mathrm{L}\right)$ & -0.427 & 0.167 \\
PPT $($ second) & 0.238 & 0.456 \\
APPT (second) & 0.266 & 0.404 \\
\hline
\end{tabular}

* Spearman correlation test

TABLE 5 presents the relationship between laboratory variables including plasma $\mathrm{D}$-dimer level with GCS score in patients with edema and cerebral or intracranial hemorrhage. A strong significant negative correlation between plasma D-dimer level $(\mathrm{r}=-0.709 ; \mathrm{p}=0.000)$ or PPT $(r=-0.594 ; \mathrm{p}=0.000)$ with GCS score were observed. Conversely, a significant positive 
correlation was shown between haemoglobin ( $\mathrm{r}$ $=0.447 ; \mathrm{p}=0.012$ ) with GCS score.

TABLE 5. Correlation between laboratory variables including plasma D-dimer level with GCS score in patients with edema and cerebral or intracranial hemorrhage $(n=31)$

\begin{tabular}{lcc}
\hline \multirow{2}{*}{ Variables } & \multicolumn{2}{c}{ GCS } \\
\cline { 2 - 3 } & $\begin{array}{c}\text { Correlation } \\
(\mathrm{r})\end{array}$ & $\mathrm{p}$ \\
\hline D-dimer $(\mathrm{ng} / \mathrm{dL})$ & -0.709 & $0.000^{*}$ \\
Hacmoglobin $(\mathrm{g} / \mathrm{dL})$ & 0.447 & $0.012^{*}$ \\
Leucocytes $(\mathrm{x} \mathrm{10} / \mu \mathrm{L})$ & -0.209 & 0.260 \\
Platelets $\left(\mathrm{x} 10^{3} / \mu \mathrm{L}\right)$ & 0.206 & 0.267 \\
PPT $($ second) & -0.594 & $0.000^{*}$ \\
APPT (second) & -0.319 & 0.080 \\
\hline
\end{tabular}

*Pearson correlation * significant if $p<0.05$

\section{DISCUSSION}

Laboratory-based predictors may be an important adjunct in the evaluation of TBI, especially in light of the concerns regarding the increased use and adverse effects of head CT scan. Several laboratory-based predictors have been investigated to predict TBI. ${ }^{9,10,13}$ Swanson et $a .^{9}{ }^{9}$ evaluated the association between PT, PTT, s100â and D-dimer with TBI on head CT scan. It was found that plasma D-dimer levels were associated with TBI. However, PT, PTT and s100â were not. Meanwhile, Bayir et al. ${ }^{13}$ determined the usefulness of fibrinolytic markers as early prognostic indicators in patients with isolated head trauma. The authors found a marked negative correlation between GCS and PT, PTT, fibrin degradation products (FDP) and plasma D-dimer levels. Moreover, mortality was most strongly related to GCS, PT, FDP and plasma D-dimer levels. In addition, Kuo et al. ${ }^{10}$ reported that a high plasma D-dimer level was associated with a poor outcome in patients with traumatic intracranial hemorrhage. This study found a significant negative correlations between plasma D-dimer levels, neutrophil as well as PPT and GCS score. Conversely, a significant positive correlation was shown between haemoglobin and GCS score.

Among laboratory-based predictors of TBI investigated by some authors, ${ }^{9,10,13}$ plasma Ddimer provides consistent results indicating that plasma D-dimer is a good predictor of TBI. Ddimer is a small protein fragment present in the blood after a blood clot is degraded by fibrinolysis. D-dimer testing has become an important test performed in patients suspected of thrombotic disorders such as deep venous thrombosis, pulmonary embolism or disseminated intravascular coagulation. ${ }^{14}$

D-dimers are not normally present in human blood plasma, except when the coagulation system has been activated, for instance ina TBI. The TBI activates tissue factors (TF) and initiates the formation of blood clot or coagulation process. The TF forms a complex with FVIIa in blood vessel, activates FX and leads to the generation of thrombin. The thrombin turns the soluble blood protein fibrinogen into fibrin. Another thrombin-generated enzyme, factor XIII, then cross-links the fibrin at the D fragment site which is then degraded by plamin to form Ddimer. ${ }^{10,14,15}$

The negative correlataion between neutrophil and GCS found in this study could be related to immunological or inflammatory response in patient with TBI. Moreover, the negative correlation between PPT and GCS score could be related to extrinsic coagulation pathway disturbances, whereas the positive correlation between haemoglobin and GCS score could be related massive blood loss in TBI.

\section{CONCLUSION}

A strong negative correlation between the plasma D-dimer levels and GCS is observed in patients with TBI indicating that the plasma 
D-dimer level may be useful as a prognostic indicator in the patients.

\section{ACKNOWLEDGEMENTS}

The authors would like to thank all patients who participated in this study.

\section{REFERENCES}

1. Bruns J, Hauser WA. The epidemiology of traumatic brain injury: a review. Epilepsia 2003; 44(10):2-10.

2. Letarte P. The Brain, In: Feliciano DV, Mattox KL, Moore EE, editors. Trauma, $6^{\text {th }}$ ed. New York: McGraw Hill Professional, 2008: 397-418.

3. Wulandari IS. Neuron-specific enolase serum sebagai prediktor kematian cidera kepala. [Tesis]. Yogyakarta: Bagian Patologi Klinik, Fakultas Kedokteran, Universitas Gadjah Mada/RSUP Dr Sardjito; 2010.

4. Morgado FL and Rossi LA. Correlation between the Glasgow Coma Scale and computed tomography imaging findings in patients with traumatic brain injury. Radiol Bras 2011; 44(1):35-41.

5. Davies HE, Wathen CG, Gleeson FV. The risks of radiation exposure related to diagnostic imaging and how to minimize. BMJ 2011;342:d947. Doi: 10.1136/bmj.d947.

6. Hoffmann ME, John OJ, Gaddis G. Utility of initial D-dimer assay in screening for traumatic of spontaneous intracranial hemorrhage. Acad Emerg Med 2001; 8(9): 859-65.

7. Tian HL, Chen H, Wu BS, Cao HL, Xu T, Hu J, et al. D-dimer as a predictor of progressive hemorrhagic injury in patients with traumatic brain injury: analysis of 194 cases. Neurosurg Rev 2010; 33(3):359-65.
8. Pikula A, Beiser AS, DeCarli C, Himali JJ, Debette $\mathrm{S}$, Au R, et al. Multiple biomarkers and risk of clinical and subclinical vascular brain injury: the Framingham Offspring Study. Circulation 2012; 125(17):2100-7.

9. Swanson CA, Burn JC, Peterson BM. Low plasma D-dimer concentration predicts the absence of traumatic brain injury in children. J Trauma 2010; 65 (5). 1072-7.

10. Kuo JR, Lin KC, Lu CL, Lin HJ, Wang CC, Chang $\mathrm{CH}$. Correlation of a high D-dimer level with poor outcome in traumatic intracranial hemorrhage. Eur J Neurol 2007; 14(10):1073-8.

11. Dale S, Gogstad GO, Brosstad F, Godal HC, Holtlund J, et al. Comparison of three D-Dimer assays for the diagnosis of DVT: ELISA, latex and an immunofiltration assay (NycoCard DDimer). Thromb Heamostas 1994; 71(3):270-4.

12. Anonim. Panduan pemantapan mutu laboratorium klinik. Himpunan Kimia Klinik Indonesia. 2005.

13. Bayir A, Kolkan E, Kocak S, Ak A, Cander B, Bodur S. Fibrinolytic markers and neurologic outcome in traumatic brain injury. Neurol India 2006; 54(4):362-5.

14. Adam SS, Key NS, Greenberg CS. D-dimer antigen: current concepts and future prospects. Blood 2009; 113(13):2878-87.

15. Antovic J, Bakic M, Ignjatovic G, Milenkovic Z. Blood coagulation and fibrinolysis parameter changes after various type of brain damage. Med Biol 1998; 5:44-9. 